\title{
Status of the development of corporate social responsibility in China and suggested countermeasures for improvement
}

\author{
Wenzhong Zhu' ${ }^{1}$, Min Zhang ${ }^{2}$ \\ ${ }^{1}$ School of English for International Business and Researcher of Research Center for Cantonese Merchants, Guangdong University of \\ Foreign Studies, Guangzhou 510420, China \\ ${ }^{2}$ Postgraduate student of SEIB, Guangdong University of Foreign Studies, Guangzhou 510420, China
}

\section{Email address:}

wenzhong8988@sina.com(Wenzhong Zhu)

\section{To cite this article:}

Wenzhong Zhu, Min Zhang. Status of the Development of Corporate Social Responsibility in China and Suggested Countermeasures for Improvement. Science Journal of Business and Management. Vol. 1, No. 4, 2013, pp. 98-103. doi: 10.11648/j.sjbm.20130104.16

\begin{abstract}
There is a growing recognition that firms that practice Corporate Social Responsibility (hereinafter referred to as CSR) actively perform better both socially and economically than those that are inactive. In China, CSR has drawn increasing attention in recent years. Despite the progress which has been achieved, CSR in China is still in its infancy. This paper traces the emergence and evolution of the concept of CSR and points out the CSR progress that China has achieved and the problems that China is facing now. It is suggested that joint efforts should be made by the government, corporations, media, and NGOs to form a mature CSR system with Chinese characteristics.
\end{abstract}

Keywords: Corporate Social Responsibility, CSR Progress, CSR Problem, Countermeasure

\section{Introduction}

In recent years, Chinese mainstream media like CCTV and China Daily have reported a series of business scandals such as "Sudan Red Event"” in 2005, "Sanlu Milk Powder Event" in 2008, "Foxconn Employees Jumping to Death" and "Honda Employees Strike in China" in 2010, Food security problems in 2011, etc. These reports immediately aroused a sensation among the public and caused a reflection on CSR in both the academic filed and the business world. Since then, CSR has become a significant concept which draws more and more public attention. There has been a rise of CSR awareness in China, with mushrooming CSR research teams, academic articles and public publications appearing and a wider participation from top to down. When all sectors of society are making efforts to achieve our nation's grand goal of building a harmonious society, corporations, as a part of society, should undoubtedly shoulder relevant social responsibilities. This paper offers an overview of the evolution of CSR theory. Then, CSR progresses and problems in China are pointed out and solutions and countermeasures to the problems are provided, so as to provide relative information for foreign academic researches and business people as references.

\section{The Evolution of CSR}

The concept of CSR is not brand new, but it has evolved considerably in the last few decades. The concept of CSR was first broached by Oliver Sheldon in 1924 and CSR has since been construed to mean that corporations not only have economic and legal obligations but also assume social responsibilities beyond these obligations. The modern era of social responsibility, however, may be marked by Howard R. Bowen's 1953 publication of Social Responsibilities of the Businessman, considered by many to be the first definitive book on the subject. In this book, he tried to give systematic and rationalized arguments in favor of CSR by stating that big corporations should consider using their power and influence with social consequences and responsibilities in mind (Bowen, 1953). The main argument to this point came from Milton Friedman (1962) who argued that the "only responsibility of a corporation is to its shareholders", and Friedman (1973) similarly argued that the social responsibility of business is to increase its profits to investors. Academics were divided between the two arguments for a decade without advancing a lot. Based on the study of his predecessors, Carroll (1979) 
advanced a brand new conceptual framework. He took CSR as the sum of obligations that an enterprise was expected by society to fulfill, and built a four-dimensional CSR model that was generally adopted in academia. Carroll pointed out that social responsibility"must embody the economic, legal, ethical, and discretionary categories of business performance", with economic responsibility at the bottom of the pyramid and the discretionary at the top. Then R. Edward Freeman(1984) put forward the stakeholder theory in his book Strategic Management: A Stakeholder Approach, identified and modeled the groups which are stakeholders of a corporation, and described and recommended how management can give due regard to the interests of those groups. He suggested that corporations' social responsibility should be to satisfy multiple stakeholders. Lantos (2001) concluded that strategic CSR is good for business and society and advised that marketing takes a leading role in strategic CSR activities. Husted, B. W., et al. (2006) researched on Corporate Social Responsibility in the Multinational Enterprises based on Strategic and Institutional Approaches, and found that institutional pressure was more powerful than strategic benefits in driving these businesses to be socially responsible. Falck and Heblich (2007) concluded that by practicing CSR strategically, a company can 'do well by doing good'; in other words, it can make a profit and make the world a better place at the same time. CSR is regarded as voluntary corporate commitment to exceed the explicit and implicit obligations imposed on a company by society's expectations of conventional corporate behavior. Companies can support this procedure and in doing so, gain profits at the same time. On November 1st, 2010, the International Organization of Standardization published ISO 26000:2010, Guidance on social responsibility, which proposed seven core subjects of CSR - human rights, labor practices, the environment, fair operating practices, consumer issues and community involvement and development.

In summary, CSR has been defined or conceptualized in a number of different ways by different scholars and in its various definitions the term has encompassed a wide range of economic, legal, and voluntary activities. The review indicates the evolution of the CSR concept experiences a shift from "obligations" to "strategy" in the West: the traditional approach is passive, to fulfill CSR as an obligation, while the new approach is positive, to make CSR a strategy, which can improve the competitiveness of the firm and support the corporate objectives as well. What about the development status of CSR theory and practice in China? The paper will make a comprehensive analysis of the issue so as to make some recommendations of further development.

\section{CSR Progress in China}

Although the term CSR was widely used in other countries as early as the 1970 s, it is a relatively new concept in China. China's CSR movement began with anti-sweatshop campaigns in 2005 and today has been into a new era after several years' development. The whole society, including the government, corporations, non government organizations (hereinafter referred to as NGOs), academia and research institutions so forth, have been involved in the development of CSR. These different social sectors concern CSR from various prospective, which promotes China's CSR to be a social movement and have promoted and advocated various CSR practices at home in recent years.

\subsection{The Government}

The Chinese government is quite actively pursuing CSR in recent years and plays an important role in promoting CSR development at home. In 2005, President $\mathrm{Hu}$ Jintao declared that the country should construct a "harmonious society" and put forward the socio-economic goal of the Chinese government, which provides a favorable political and social environment to encourage CSR development. Besides, a number of laws, regulations, and policies related to CSR have been issued in China. For example, the China Social Compliance 9000 (CSC 9000) developed in 2005 for the textile industry which is China's first CSR management standard has obtained worldwide recognition. The new Corporate Law, which went into effect on January 1st, 2006, requires companies to "undertake social responsibility" when doing business. Another important state-led measure is the promulgation of the CSR principles in 2008 for the state-owned enterprises controlled by the central government, which is an important legal document explaining the Chinese central government's attitude towards CSR. In addition, in recent years, the government authority of securities and stocks has required all public listing companies to announce CSR annual reports to the general public and investors.

\subsection{Corporations}

China's corporations have shown an increasing awareness of CSR and the focus of CSR has stepped from academic scholars' discussions to corporations' practice. The number of companies in China developing CSR reports is growing. Before 2005, some Chinese companies reported their CSR information as part of their annual financial report. For example, the China National Petroleum Corporation (CNPC) released its first financial report in 1996 covering safety, health, and environmental information. Since 1999, CNPC added information about employees and philanthropic activities to its financial report. In 2005 and 2006, the major state-owned corporations, such as the CNPC and the China Petrochemical Corporation (Sinopec), started establishing CSR reporting mechanisms and releasing their first independent annual CSR reports. Generally, these reports include companies' practices and achievements in carrying out their economic, environmental, and social 
responsibilities. The reports are prepared in accordance with international CSR reporting standards, such as the Global Reporting Initiative (GRI). Recent years has witnessed a dramatic increase in the number of companies releasing CSR report. Over 570 CSR reports were released from January 1st to October 31st, 2009, far more than that released in the year of 2008 (169 reports) (CSR-CHINA, 2009). In addition, some corporations have been positively exploring ways to make CSR as the business strategy and daily management to establish a comprehensive CSR management system.

\subsection{NGOS}

The involvement of NGOs has also risen, which has played a significant role in raising public awareness regarding responsible business practices in many developed nations such as the US, Australia, and UK. The NGOs has enhanced the recognition of corporate citizenship and formulated and promoted the code of industrial ethics and the development of corporate citizenship. In recent years, the political and social environment for NGOs in China has become more open as the Chinese government is beginning to realize the positive impact of NGOs. NGOs, especially the grassroots NGOs, are encouraging greater responsibility and sustainability of business practices in China, so their impact cannot be overlooked. In China, one of the most developed provinces, Guangdong as an experiment region of Chinese reform, is now implementing a new reform of government administration mechanism, aiming to empower official power to NGOs, which may be a beginning of the whole nation's new round of deep reform.

\subsection{Academia and Research Institutions}

Chinese universities and research institutions, such as Peking University and the Guangdong Academy for Social Sciences, have been actively researching CSR issues in recent years. They provide a theoretical foundation for CSR practices in China by publishing theoretical researches on CSR, case study compendiums of CSR initiatives, and guidelines for evaluating CSR and by holding frequently international symposia and seminars throughout the country. Besides, CSR scholars have produced numerous publications and actively attended CSR events to deepen the CSR discussion in China. In Beijing, University of International Business and Economics has established a joint research center of business ethics, conducting business ethics studies and holding CSR conferences every year. In southern China, Guangdong Academy for Social Sciences has set up the first association of CSR with Dr. Li Youhuan as chairman, which has produced a large number of academic achievements including books, papers and journals. And more recently, this association has focused on a leading research on ISO26000, and several related books of ISO26000 have been published by the research members since 2010 (Li, 2013).

\section{CSR Problems in China}

\subsection{Problems of CSR Theory Study in China}

The CSR concepts and dimensions used by domestic scholars are to a great extent built upon the findings of academic studies in the United States and Europe, and few Chinese scholars have made any attempt to make an empirical measurement of CSR under China's unique social and cultural background. So, indigenous CSR study is relatively lacking in China.

In 2006, the Market Economy Academy at Peking University published China's Corporate Social Responsibility Survey Evaluation System and Criteria under which the key indicators of corporate social responsibility include: shareholder interests, social and economic interests, employee benefits, legal responsibility, operation in good faith, charitable responsibility and environmental protection. Based on his survey of 986 enterprises on CSR in 2006, it found the three key indicators of China's CSR were productive environmental expenditures, labor and social security outlays and tax payments. While such studies represent a fruitful exploration of CSR theory in China, most of them are still intended to validate CSR theories built upon the enterprises of developed western countries. Interestingly, few scholars have made a study of CSR in light of China's unique circumstances.

However, because CSR performance and recognition are influenced by cultural and social backgrounds, and CSR dimensions varied from time to time in different social and cultural ambiances (Tian, 2005), undertaking indigenous study based on China's peculiar circumstances, exploring and identifying CSR dimensions in China, and building a set of CSR concepts in tandem with China's specific social background, are of realistic significance to further CSR study in China.

\subsection{Problems of CSR Practice in China}

The year 2004 is a watershed of CSR for corporations in China, in which some multinational corporations put social responsibility certification on corporations in China. CSR practices in China consist of three major periods. The first is the introduction stage from 1996 to 2000, during which Chinese corporations were forced to accept the CSR requirements abroad. The second is the stagnated stage from 2000 to 2004. In order to promote the development of CSR in China, academic institutions, governmental organizations and non-governmental organizations began to do some deeper research on CSR. Ministry of Labor, Ministry of Commerce and Confederation of Enterprises in China (CEC) built CSR research groups respectively. The third is the participation stage from 2004 to present. Afraid of economic sanctions and trade barriers, the Chinese government has taken a positive instead of passive attitude to carry out CSR movement hoping to enhance the international competitiveness of China. In January 2006, 
the First International Forum on Chinese Corporate Social Responsibility was jointly convened by the government, enterprises, research institutes and the media. In July 2006, a Chinese Corporate Social Responsibility Survey was launched nationwide. Moreover, a workshop on "the mission of entrepreneurs for social responsibility" was organized by Shenzhen municipal leaders and corporate executives.

Following more than two decades of economic growth, China has to face the negative effects of over-rapid economic development. For example, myopic vision has led enterprises to exploit the environment and cheat their customers for short-term gains, and has in consequence widened the gap between the rich and poor, and intensified social contradictions. China's sustainable economic and social development has been impeded due to such problems, and all circles of society have now realized that enterprises must take up their social responsibilities. As a result, the western concept and theory of CSR has become a red-hot topic attracting the utmost attention of government, academia and enterprises in China.

While western researchers have failed to arrive at a unified concept and dimension of CSR, we have more limited knowledge of CSR under the global backdrop. The existing concepts and measuring indicators of CSR, however, have all been designed by western scholars according to their specific cultural background and institutional arrangement using western samples. Therefore, we cannot help but ask: Are western CSR concepts and dimensions suitable for Chinese practice? Does western CSR theory work under China's unique social and cultural background? However, the situation of CSR practice in China is so worrying today.

Firstly, most enterprises do not set up the concept of CSR in our country. They think that is only a waste of resources, ending in reducing enterprise profitability if an enterprise assumes CSR. Therefore, these enterprises are not willing to assumes CSR initiatively, just mere pursuit to maximize the profit of shareholders, neglect the protection and improvement of environment and participate charities, etc. Only these large state-owned enterprises' performance of CSR is better, a lot of small and medium enterprises have no strength or no intention to perform CSR. Clearly it can be seen that the CSR practice in China is still at a preliminary stage and it has not been fitted into corporate strategic management and the construction of corporate core competitiveness.

Secondly, there exists the absence of governmental supervision and control of CSR practice in China. It is true that China has made some efforts to enact and put into force several laws and regulations on CSR, but that is far from enough. Every day we hear different issues, for example, infringement of consumer interests and rights caused by food insecurity, harm of labor interests and rights caused by unsafe production, non-compliance with the law and the pursuit of economic interests at the cost of the waste of resources and destruction of the environment, and tax evasion against the national interest, etc. By far, China has not founded official CSR organizations, neither promulgated internationally recognized CSR standards, thus leading to the high cost of CSR performance for Chinese enterprises.

Thirdly, there exists a serious absence of non-governmental supervision and control of CSR. The fact is that the number of specialized CSR associations, whose functions and influence is so limited, is so tiny, and that the influence of Trade Union in China is not that strong, either. Although the progress of China's CSR development is encouraging, it is necessary to realize that there are still numerous problems hindering the further development of CSR in China.

Fourthly, the overall level of China's CSR is still at a low stage. In spite of the progress which has been achieved, the number of companies involved remains relatively small. Based on the press conference on "2009 China's Corporate Social Responsibility Blue Book" and Development of CSR of Top 100 China's Corporations held by Chinese Academy of Sciences (CAS) in October in 2009 in Beijing, approximately one fifth of China's top 100 corporations are at the start stage of CSR without sound ideas and systems. Roughly $40 \%$ of China's top 100 corporations had little awareness of CSR as bystanders. For small and medium sized corporations, CSR tends to mostly involve short-term actions. Most Chinese corporations take CSR measures mainly to prevent misconduct, rather than an attempt to increase corporate value in the marketplace through strategic CSR. It is still rare to find companies that fully integrate CSR initiatives in every part of their organizations whereas CSR in the West has moved beyond this and is being integrated into a company's long-term strategic planning.

Fifthly, there are some limits and restrictions on the development of grassroots NGOs. Generally, there are two kinds of NGOs in China: government-organized NGOs (GONGOs) and grassroots NGOs. Some scholars point out that GONGOs are not "pure" NGOs because of their close relations with the government. Grassroots NGOs are important players in CSR, as they provide program implementation advice to companies. However, most of them don't have sufficient intellectual or financial resources to plan and run social initiatives in-house. Besides, grassroots NGOs, which form the largest group of NGOs in China, are seldom targeted for corporate partnerships because they often lack the legal status to issue receipts. In contrast, most companies partner with GONGOs because they have state approval to work with disadvantaged communities and are allowed to issue charitable receipts to Chinese donors. However, some common complaints about GONGOs involve their financial opacity and inefficiency. Therefore, it is reasonable to predict that the underdeveloped nature of NGOs is a limiting factor to the development of CSR in China.

In addition, the overall performance of CSR reporting practices in China is not satisfying. In the light of the 
results of the research on CSR reporting in China (2001-2009) by the Development Center for Chinese CSR of China WTO Tribune (CSR-CHINA, 2009), of the 541 reports received in 2009, about half are found structurally deficient and very limited in information disclosure, whether in terms of depth or breadth, leading to quite limited communication with stakeholders. Disclosure of social performance is relatively good, while disclosure of environmental performance is rather weak, with disclosure of economic performance standing somewhere in between. Chinese CSR reports are below the level of international practice. Only $2.2 \%$ of CSR reports under research are prepared in both Chinese and English, 7.8\% made reference to Global Reporting Initiative "Sustainability Reporting Guideline "(GRI G3), and 6.1\% are verified by independent third-party auditing organizations. Quality of reports varies significantly. Central state-owned enterprises enjoy a much higher reporting performance than the average level of Chinese CSR reporting practices. Growing enterprises and private enterprises indeed published a number of high-quality reports, but most of CSR reports from them await further improvement. What's worse, many companies decide to issue a CSR report just to enhance their corporate image or to satisfy government requirements.

Finally, CSR awareness among consumers is generally low. Since CSR in China does not evolve as a response to local consumer demands, and there is little pressure from the market to implement CSR. What's more, because market competition in China is still based mainly on price, companies face immense cost-saving pressures, making it easy for some of them to justify their "license to operate" status in an unethical manner.

\section{Solutions to the CSR Problem in China}

Firstly, it is necessary to the firm to form a common sense on CSR in China. Without a common sense on CSR, it is impossible for corporations to fully fulfill their social responsibilities. A modern corporation should assume the following responsibilities: 1) Economic responsibilities. Corporations have a responsibility to produce goods and services that society wants and to sell them at a profit. 2) Legal responsibilities. Just as society has sanctioned the economic system by permitting business to assume the productive role, as a partial fulfillment of the "social contract, "it has also laid down the ground rules-the laws and regulations- under which business is expected to operate. Society expects business to fulfill its economic mission within the framework of legal requirements. 3) Ethical responsibilities. Ethical responsibilities are additional behaviors and activities that are not codified into law but nevertheless expected of business by society's members. 4) Discretionary responsibilities. Corporations are expected to carry out voluntary activities such as making philanthropic contributions, conducting in-house programs for drug abusers, thus becoming a satisfying corporate citizen. Furthermore, corporations should incorporate the concept of CSR in every process of their decision making and make CSR a strategy for their development. At the same time, it is key for the corporation to perfect its corporate governance structure and CSR management system so that the interests of all stakeholders will be considered in business decisions and business operation activities.

Secondly, it is necessary for the government to set up law enforcement committees for the inspection of the law enforcement at the grass-root levels. In this way, laws and regulations can be ensured to be consistently enforced at the national and local levels. Chinese government is expected to offer more manpower and material support for CSR grassroots NGOs by amending relevant laws like the Charity Law. Meanwhile, public funds should be more inclined to grassroots organizations. According to the State Council's "Regulations for the Management of Foundations" (China Youth Development Foundation, 2007), only public foundations are allowed to legally conduct public fundraising. As a result, grassroots NGOs' financial support mainly comes from targeted fundraising within a limited circle of acquaintances and business contacts. Besides, many CSR grassroots organizations in China still suffer from lacking legal identification. As grassroots NGOs are playing an important role in promoting the development of CSR in China, relevant laws should include more contents on how to support the development of NGOs from a managerial perspective, rather than set a series of limitations restricting its development. And industry leaders need to reform their ideas about grassroots NGOs, from rejecting them as small, petty organizations to supporting their projects and sustainability. In addition, raising the awareness of the general public and employees is also necessary to develop CSR initiatives. For instance, in 2009, Shanghai's municipal government sponsored a social venture competition, in part to raise the awareness of CSR-related issues. The general public should also be reminded that they, in addition to the government and investors, represent an important group of stakeholders. The government can accelerate the process by mandating the publication of CSR-related information in a central repository, such as in annual reports, thus encouraging information sharing among stakeholders to help CSR activities develop efficiently and effectively.

Finally, the media should shoulder the responsibility of disclosing relevant information to the whole society and increasing public awareness of CSR. This will ensure that relevant information is accessible for all stakeholders, which will, in turn, improve the quality of CSR activities. The media should act as channels for dialogue and for interaction between society and corporations. It should constitute a powerful mechanism of monitoring and take on the accountability on behalf of the people. The most important thing is that media coverage on CSR must be transparent and accountable. As for companies who 
sincerely try to do good for their community by committing their human and financial resources to developmental projects, media should give them positive publicity. Such publicity will in turn inspire other organizations to get involved, thus bringing about more initiatives that will benefit the society and will enhance a cycle of sustainability. On the contrary, for CSR scandals, media should disclose them bravely and objectively. To meet this challenge, it is important for the media to enhance its understanding of the field and to realize their important roles and great responsibilities in the society.

\section{Conclusion}

Although CSR is a concept that has attracted worldwide attention and acquired a new resonance in the global economy, no universally acceptable definition of CSR exists. But we can see the CSR concept has "a shift from obligation to strategy": the traditional approach is passive, to fulfill CSR as an obligation, while the new approach is positive, to make CSR a strategy to improve the competitiveness of corporations. CSR in China is moving rapidly from conceptual study into implementation. And China is developing a healthy CSR trend to foster CSR, which can generate a virtuous circle of benefits to business and Chinese society. However, it must be realized that CSR in China is still in its infancy. Methods, tools and approaches are still being tried out, and various problems need to be tackled. The paper suggests that the government, corporations, media, and NGOs should make joint efforts to form a mature CSR system with Chinese characteristics in order to resolve the developing problems of CSR in China.

\section{References}

[1] Bowen, H. R. Social Responsibilities of the Businessman. New York: Harper, 1953.
[2] Friedman, M. The Social Responsibility of Business Is to Increase Its Profits. The New York Times Magazine, September 13th, 1973:173-178.

[3] Carroll, A. B. A Three-Dimensional Conceptual Model of Corporate Performance.1979, The Academy of Management Review, Vol. 4, 1979, pp. 497 - 505.

[4] Freeman, R.E. Strategic Management: A Stakeholder Approach. 3rd. New York: Cambridge University Press, 1984.

[5] Lantos, G. P. "The boundaries of strategic corporate social responsibility", Journal of Consumer Marketing, Vol. 18 Iss: 7, 2001: pp.595-632.

[6] Husted, B. W., et al. Corporate Social Responsibility in the Multinational Enterprises: Strategic and Institutional Approaches. Journal of International Business Studies, 2006: 838-849.

[7] Falck, O., Heblich S. Corporate Social Responsibility: Doing Well by Doing Good, Business Horizons, Elsevier Science Inc., USA, Vol. 50, Issue 3, 2007: 247 - 254.

[8] Tian Muyu. Confucian Culture and its Influence over Modern Business Management. Market Weekly, 2005.

[9] Li Youhuan. Brief introduction to Professor Li Youhuan. http://baike.baidu.com/view/1583048.htm, 2013.

[10] CSR-China, 2009. Research on CSR Reporting in China (2001-2009) Reveals Four Main Findings. Available at: http://www.csr-china.net/templates/node/index.aspx?nodeid $=$ ddd0b45c-b7c4-4947-b2e3-e20374708733\&l=en\&page $=c$ ontentpage $\&$ contentid $=49 \mathrm{f} 15 \mathrm{aa} 0-\mathrm{f} 43 \mathrm{c}-4096-\mathrm{bda} 4-99 \mathrm{cbac} 54$ $70 \mathrm{~cd}$.

[11] China Youth Development Foundation, 2007. Regulations for the Management of Foundations. Available at: http://www.cydf.org.cn/en/sys/html//m_8/2007-11-02/19424 4.htm. 